\title{
Efficiency of measures and technology to preserve soil fertility and protect the soil from erosion in the steppe regions of the Southern Urals
}

\author{
V.Yu. Skorokhodov*, A.A. Zorov, D.V. Mitrofanov, Yu.V. Kaftan, and N.A. Zenkova \\ FSBSI "Federal Scientific Center of Biological Systems and Agrotechnologies of the Russian \\ Academy of Sciences", Gagarin ave, 27/1, 460051, Orenburg, Russia
}

\begin{abstract}
The main source of soil fertility decline in the arid conditions of the Orenburg region is erosion, which manifests itself to varying degrees over the entire arable land. In the Orenburg region, 2214.9 ha are subject to water erosion, wind erosion - 279.4 ha, and out of a total area of 6240.0 thousand hectares, deflationary hazardous erosion - 5304.3 thousand hectares. In connection with erosion processes, the humus content in the soil decreases by 1-6 tons in southern chernozems, ordinary $-1.7 \%$. The studies were carried out in two stationary areas of the Orenburg Cis-Urals and Trans-Urals in order to determine the efficiency of measures and technologies to preserve soil fertility and protect the soil from erosion in arid conditions. With the transition to contour-landscape agriculture (CLA), the fertility of slope lands and the yield of field crops increases, and the negative effect of drought decreases to a minimum. The decrease in soil fertility caused by the erosion process is recorded in the fallow field when it is allocated for spring wheat. Soil-protecting and green fallows largely eliminate this disadvantage. During the fallowing period as per the data, the field of black fallow accumulates $430 \mathrm{~kg}$ per 1 ha of nitrates in the 0-150 cm layer, and when mineral fertilizers are applied at a dose of $\mathrm{N}_{40} \mathrm{P}_{80}$, it increases to $689 \mathrm{~kg}$ per 1 ha.
\end{abstract}

\section{Introduction}

A significant part of Russia's agricultural land is subject to various types of negative erosion processes causing soil degradation, damaging land resources and the environment. The main task of the agrarians is to stop the destructive effect of erosion with the return of the lost soil fertility. The main sources of the soil fertility decline in the arid conditions of the Orenburg region is soil erosion, which manifests itself to varying degrees throughout the entire arable land. Out of a total Orenburg region soil area of 6240.0 thousand hectares, 2214.9 thousand hectares are subject to water erosion, wind erosion - 279.4 thousand hectares, and deflationary-dangerous arable land is 5304.3 thousand hectares. Humus content decreased by: typical chernozems - 3\%, common - 1.7 , southern - 1.6 and dark

* Corresponding author: skorohodov.vitali1975@mail.ru 
chestnut soils - $1.0 \%$ [1.2]. In the Central chernozem region and the Ural region, $50-60 \%$ of the arable land is erosion-prone, and in the North Caucasus and the Volga region, the area of eroded lands increases to $90 \%$ [3].

In sharply dry years, wind erosion manifests itself on a vast area of the territory of Kazakhstan and Russia. In spring, dust storms were observed not only on fallow fields, but also on plowlands, as a result of which the top fertile soil layer is lost [4]. Studies by Suleimenov M.K. and Akshalova K.A. showed that on the slopes of Northern Kazakhstan in a fallow field due to soil washout, up to 6.1 tons of soil per hectare are lost [5].

The problem of soil and water protection organization of slope lands is very urgent. Without preserving soil fertility, there is no sustainability of agriculture and decrease in productivity. Unregulated runoff and the volume of soil moisture are the causes of erosion processes. Introduction of soil-protective field crop rotations is one of the priority tasks of modern agriculture [6]. Crop rotations including clean fallow in their structure are unstable in terms of erosion and intensifying erosion processes, since losses from the runoff of melt and storm water are added to the generally accepted losses of soil moisture. Due to the drift and washout of the upper fertile layer, there is a sharp decrease in yields of all cultivated agricultural crops [7].

The contour-buffer strip organization on the slopes consisting of perennial grasses and shrub bushy plants reduces moisture loss by $30 \%$, soil - by $50 \%$, and the yield of agricultural products increases by 4.2 times [8].

A.I. Klimentyev notes that recently, water erosion has become widespread in the eastern regions of the Orenburg Trans-Urals, where the slopes do not exceed 0.2-1.5 degrees. A significant part of the arable land is located on these slopes, which, as a rule, are of great length. Large watershed areas and slow soil thawing during the snow melting period, as well as strip farming and wings sowing created to protect soils from wind erosion and snow accumulation often coincide with the direction of these slopes, which leads to intensive runoff and soil washout, and in some spring washout periods reaches $15-25 \mathrm{t} / \mathrm{ha}$ in fallow and plowland [9].

The development of erosion processes occurring in the soils of the region is the result of their misuse. The following has contributed to the strengthening of water and wind erosion: continuous plowing of soils without proper consideration of their quality, the use of template agricultural techniques, as well as the poor knowledge of eroded soils, methods of their protection [10].

In the arid conditions of the Southern Urals, water erosion is provoked by the runoff of melt water and heavy rains. Its development occurs in two periods during the year. The first is the spring snowmelt when the runoff flows through the frozen soil, the second rainstorms (May-September). The soil freezing depth, the thickness of the snow cover with a large supply of water in it, the increased soil moisture at the beginning of the runoff, the weather nature and agricultural background form the surface runoff of melt water. Surface runoff of melt and storm water on different agricultural backgrounds largely depends on soil and climatic conditions.

The development and implementation of effective measures and technologies to preserve soil fertility and protect soil from erosion remains one of the main tasks of agricultural science and for the steppe regions of the Orenburg region.

The arable layer density is reduced with deep bursting; this contributes to a greater accumulation of autumn-winter-spring precipitation, an increase in the snow cover thickness is provided due to first snow deposition and the prevention of its blowing out on the stubble agricultural background, oppression and shallower soil freezing depth, reduced evaporation, high soil protection effect, preservation of soil structure from destruction, elimination of potential erosion danger and increase of anti-erosion resistance, water runoff and soil washout are prevented, and it decreases in the soil layer during dust storms [11]. 
In the Orenburg region, $50 \%$ of the arable land is erosion-prone and is located on slopes from 1 to 7 degrees.

Many agrotechnical methods have been developed to protect the soil on the slopes from water erosion, including the contour-strip organization of each crop rotation field instead of the rectangular-cell one. Contour-landscape agriculture (CLA) includes contour deep moldboard-free tillage with stubble preservation, leaving plant residues and straw in the mulch form on the soil surface, soil-protective crop rotations with contour-strip placement of perennial grasses, fallow and tree-shrub wings [12].

\section{Materials and Methods}

The studies were carried out in two stationary areas of Orenburg Cis-Urals (coordinates: $\left.51.775125^{\circ} \mathrm{N}, 55.306547^{\circ} \mathrm{E}\right)$ and Trans-Urals (51 $\left.{ }^{\circ} 45^{\prime} 53^{\prime \prime} \mathrm{N} 59^{\circ} 44^{\prime} 34^{\prime \prime} \mathrm{E}\right)$.

The objects of research were crop shifts of different rotation, fallow field.

Purpose of the study: To determine the efficiency of measures and technologies to preserve soil fertility and protect soil from erosion in the conditions of the Southern Urals

\section{Results and Discussion}

The studies carried out for 30 years on CLA and their implementation in the farms of the region showed a high agrobiological basis of this farming type on the slopes; in addition, it provides an even distribution of moisture reserves in the soil and increases them by $1.5-2.0$ times.

The use of woodland belts prevents the development of dust storms, reducing the wind speed in the summer by a factor of 2-3; during the spring-summer period, up to $30 \mathrm{~mm}$ of productive moisture is additionally accumulated in the fallow field soil.

The yield of grain crops increases by $2-5$ cwt per hectare, fodder crops - by $1.5-2.0$ times, with an increase in the profitability of their production by $2-3$ times. With the transition to CLA, the fertility of slope lands increases together with the yield of agricultural crops; it also minimizes the negative effects of drought.

Wind erosion causes great damage to soil fertility. It manifests itself primarily on light soils and fallow fields, in dry years - also on plowland.

Table 1. Approximate parameters of ecologically sustainable agricultural landscape models.

\begin{tabular}{|c|l|c|c|c|}
\hline $\begin{array}{c}\text { Slope } \\
\text { angle }\end{array}$ & \multicolumn{2}{|c|}{ Model elements } & Width, $\mathrm{m}$ & $\begin{array}{c}\% \text { to arable } \\
\text { land }\end{array}$ \\
\hline \multirow{2}{*}{$\begin{array}{c}\text { up to } \\
3^{\circ}\end{array}$} & Perennial grass buffer strips & $25-30$ & $30-35$ \\
\cline { 2 - 5 } & Inter-buffer space & $55-65$ & $60-65$ \\
\cline { 2 - 5 } & Inter-strip space of forest plantations & $1-2$ row & $100-120$ & $5-8$ \\
\hline \multirow{2}{*}{$3-5^{\circ}$} & Perennial grass buffer strips & $3-4$ row & $300-360$ & \\
\cline { 2 - 5 } & Inter-buffer space & $35-40$ & $40-45$ \\
\cline { 2 - 5 } & Inter-strip space of forest plantations & $1-2$ row & $80-50$ & $50-55$ \\
\cline { 2 - 5 } & & $3-4$ row & $240-300$ & $5-10$ \\
\hline Over 5 & $\begin{array}{l}\text { Solid grassing, afforestation of ravines, } \\
\text { gulches, combes }\end{array}$ & - & - & - \\
\hline
\end{tabular}

The morphogenetic soil properties, the aggregate composition in the presence of vegetation cover, stubble, straw in the mulch form make it resistant to wind erosion. When the ratio of soil lumps with a diameter of more than $1 \mathrm{~mm}$ to a diameter of less than $1 \mathrm{~mm}$ 
is equal to at least one in a layer of $0-5 \mathrm{~cm}$ of soil in the aggregate composition, it becomes wind resistant.

Stubble and crop residues act as deflation protection by reducing the surface wind speed. Leaving stubble on the soil surface reduces the manifestation of wind erosion on large flat areas with a dry climate.

An erosion-prone place in the crop rotation is a clean fallow field; with the destruction of stubble after two or three cultivations, the soil becomes loose and prone to volatilization, especially for sowing spring wheat.

Lumpiness for all fallow types from autumn was in the range from 58.1 to $72.4 \%$, and erodibility ranged from 8.4 to $71.2 \mathrm{~g}$ per $1 \mathrm{~m}^{2}$ in 5 minutes (Table 2). The developed technology for the application of soil-protective and green manure fallows minimizes erosion processes and makes it possible to additionally obtain fodder products in the form of green mass of Sudanese grass (up to 30 thousand fodder units per hectare).

Table 2. Elements of wind resistance and erodibility of the upper $(0-5 \mathrm{~cm})$ soil layer

\begin{tabular}{|c|c|c|c|}
\hline \multirow{2}{*}{$\begin{array}{c}\text { Indicators of wind } \\
\text { resistance and erodibility }\end{array}$} & green & bare & soil protective \\
\cline { 2 - 4 } & $0 / 0^{*}$ & $0 / 0$ & $171,0 / 60,3$ \\
\hline $\begin{array}{c}\text { Stubble quantity, pcs. per } \\
1 \mathrm{~m}^{2}\end{array}$ & $58,1 / 72,5$ & $63,6 / 70,2$ & $72,4 / 78,6$ \\
\hline Lumpiness, \% & $54,6 / 14,4$ & $71,2 / 38,3$ & $8,4 / 7,7$ \\
\hline $\begin{array}{c}\text { Erodibility, g per 1 cm } \\
\text { for 5 min }\end{array}$ & & & \\
\hline
\end{tabular}

*before the line - at the end of fallowing, after the line - after wheat sowing.

The use of green manure crops in a fallow field reliably protects the soil from deflation in the first half of summer, and when the green manures are plowed onto the surface, a structured soil layer is turned out increasing lumpiness and resistance to soil erosion.

During the growing season of the summer Sudanese grass sowing period, as in the case of green manure, the field in soil-protective fallow has natural protection from erosion, and stubble remains after harvesting.

High resistance to deflationary processes is noted for sowing durum wheat on different types of fallow due to soil structuring.

In the upper 0-5 cm soil layer, lumpiness increased in all fallow types. In the field of bare fallow in the spring, water erosion poses a great threat.

The oversaturation of the arable layer with moisture in the presence of microdepressions and slope areas leads to an increase in water erosion processes.

During water, wind and biological erosion, large losses of organic matter and nutrients occur in bare fallow. Sown fallow remedy this disadvantage. The loose structure and low moisture content of the arable layer promotes the absorption of melt water and prevents runoff in the spring.

In some years, with vigorous snow melting, the top layer in the green manure fallow is oversaturated, which leads to runoff and washout. A field with soil-protective fallow is best protected from deflation since the post-harvest stubble preservation of Sudanese grass increases the lumpiness percentage and thereby creates resistance to various erosion types. By the end of fallowing, the soil erodibility decreases by 8 and 6 times in the soil-protecting fallow compared to bare and green manure fallows. In all the years of the experiment, the soil-protecting fallow fulfilled its soil-protecting functions due to the stubble left on the surface, protecting the soil from wind erosion.

Repeated tillage with a cultivator in clean fallow leads to biological erosion (humus mineralization) and accumulates a large amount of nitrate nitrogen, which is lost due to 
water and wind erosion. One part of the nitrate nitrogen is washed into the lower horizons, the other goes into an indigestible form and becomes inaccessible to plants.

According to the experiments' results, up to $43 \mathrm{mg}$ per $100 \mathrm{~g}$ of nitrate nitrogen accumulate in the soil arable layer in some years at the end of fallowing; by the spring before sowing spring durum wheat its amount is up to $6-8 \mathrm{mg}$ or less (the rest is loss). According to long-term data, this amount of nitrate nitrogen is quite enough to obtain a high yield of wheat.

In connection with the above, clean fallows are one of the environmental pollution sources, since in a state of erosional instability, a large amount of nitrates is carried away with the soil polluting rivers and water bodies. On the southern chernozems of the Orenburg region, it was established that nitrates penetrated to a depth of $8 \mathrm{~m}$, where they were found at the bottom of the well.

The soil-protection fallow developed by the authors completely eliminates this lack of clean fallow. The dynamics of nitrates loss is different in the soil-protective fallow than in the clean one. During the fallowing period, the amount of nitrates in the soil-protecting fallow decreases as a result of the consumption by the fallowing crop.

At the end of durum wheat sowing fallowing, the arable layer contains $2.4 \mathrm{~kg}$, and 376.8 $\mathrm{kg}$ per hectare on the net.

These studies confirm the loss of nitrates in the $0-150 \mathrm{~cm}$ soil layer (Table 3 ) in the soilprotective fallow, green manure and bare fallow.

Table 3. Dynamics of nitrate nitrogen depending on the fallow type and nutrition background in soil layers of $0-150$ and $0-100 \mathrm{~cm}$, in $\mathrm{kg}$ per $1 \mathrm{ha}$.

\begin{tabular}{|c|c|c|c|c|}
\hline \multirow{2}{*}{$\begin{array}{c}\text { Term of nitrates } \\
\text { determination }\end{array}$} & \multirow{2}{*}{$\begin{array}{c}\text { Soil } \\
\text { sample } \\
\text { layer }\end{array}$} & green & bare & soil protective \\
\cline { 3 - 5 } & $0-150$ & $564511 / *$ & $621 / 455$ & $617 / 467$ \\
\hline $\begin{array}{c}\text { At the beginning of } \\
\text { fallowing }\end{array}$ & & & & $308 / 281$ \\
\hline $\begin{array}{c}\text { Before arable land transfer } \\
\text { for winter }\end{array}$ & $0-150$ & $513 / 503$ & $1310 / 885$ & $213 / 179$ \\
\cline { 3 - 5 } & $0-100$ & $391 / 387$ & $827 / 545$ & $-309 /-186$ \\
\hline $\begin{array}{c}\text { Before sowing durum } \\
\text { wheat }\end{array}$ & $0-100$ & $512 / 440$ & $574 / 428$ & \\
\hline $\begin{array}{c}\text { For the period of fallowing } \\
\text { start - arable land transfer } \\
\text { for winter, } \\
+ \text { or - }\end{array}$ & $0-150$ & $-51 /-8$ & $+689 /+430$ & $+223 /+193$ \\
\hline $\begin{array}{c}\text { For the period of arable land } \\
\text { transfer for winter - sowing } \\
\text { wheat, } \\
\text { + or - }\end{array}$ & $0-100$ & $+121 /+53$ & $-253 /-117$ & \\
\hline
\end{tabular}

* - above the line - nutrient background with fertilizers, below the line - without fertilizers.

Bare fallowing leads to the maximum accumulation of nitrates in a $150 \mathrm{~cm}$ soil layer up to 689 and $430 \mathrm{~kg} / \mathrm{ha}$ on the background of nutrition with and without fertilizers. Green manure crops and Sudanese grass in fallow fields used nitrates to form yields, which resulted in decreasing their content in the $0-150 \mathrm{~cm}$ soil layer. Before leaving for winter, bare fallow has an advantage over sown fallows in terms of nitrate content.

During spring durum wheat sowing in the 0-100 cm layer, the amount of nitrates was approximately the same for all fallow types; in bare fallow it amounted to $253 \mathrm{~kg}$ on a fertilized background and $117 \mathrm{~kg}$ per 1 ha on an unfertilized background.

Soil-protective and green manure fallows contribute to productive nitrates' losses in comparison with bare fallow, which are lost while migrating down the horizon and polluting the groundwater. In addition, due to the intensive humus migration in bare fallow, 
its losses amount to 1.73 tons per 1 ha, in the sown soil-protective (due to organic residues)

- 0.05 tons per 1 ha, green manure -0.32 tons per 1 ha.

\section{Conclusion}

1. The transition to contour-landscape agriculture (CLA) increases the fertility of slope lands together with the yield of field crops and minimizes the negative effect of drought.

2 The use of soil-protective and green manure fallows in crop rotations weakens the effect of water, wind and biological erosion and promotes humus formation.

3. During the fallowing period after bare fallow, a large amount (430 kg per $1 \mathrm{ha}$ ) of nitrates is accumulated.

4. By the end of fallowing in the soil-protective fallow, the erodibility is 8-6 times compared to pure and green manure fallows. The soil protection fallow developed by the authors for spring durum wheat eliminates the disadvantages of clean fallow.

\section{Acknowledgements}

Research is carried out in accordance with the research plan for 2021-2023. FSBSI BST RAS (No. 0761-2019-0003).

\section{References}

1. N.A. Maksyutov, A.A. Zorov, V.Yu. Skorokhodov, D.V. Mitrofanov, Yu.V. Kaftan, N.A. Zenkova, Proceedings of OSAU, 3, 9-11 (2020)

2. V.Yu. Skorokhodov, N.A. Zenkova, Plodorodie, 6 (111), 28-31 (2019)

3. I.N. Listopadov, M.V. Tekhina, Crop rotation in modern agriculture, $82-87$ (2004)

4. A.I. Barayev, Soil-protection agriculture, 381 (1988)

5. K.A. Akshalov, Crop rotation in modern agriculture, $92-97$ (2004)

6. A.V. Kislov, Crop rotations and their role in the reproduction of soil fertility / conservation and enhancement of soil fertility in adaptive landscape agriculture in the Orenburg region, 39-67 (2002)

7. N.K. Biskaev, Innovative processes in agricultural production "Science and Practice": collection of sci. art., 115-131 (2008)

8. A.I. Klimentyev, Soil-ecological foundations of steppe land use, 267 (1997)

9. V.D. Khopreninov, S.V. Khopreninov, Problems of agriculture, crop production and animal husbandry in the steppe region, 79-89 (1997)

10. G.P. Sumach, Water erosion and ways to fight it, 258 (1976)

11. N.K. Biskaev, Science and Bread, 9, 63-72 (2002)

12. V.Yu. Skorokhodov, Plodorodie, 2 (119), 55-60 (2021) 